\title{
Wing-web-stab Use Route of Administration
}

National Cancer Institute

\section{Source}

National Cancer Institute. Wing-web-stab Use Route of Administration. NCI Thesaurus.

Code C150019.

Administration of a veterinary medicinal product into the wing-web of a bird. 